\title{
The clouds against progress: technoscience, environment and the U.S./Brazil "Radar in Amazon Project" (RADAM) (1970-1975)
}

\author{
Leandro Gomes Moreira Cruz \\ Claiton Marcio da Silva
}

\begin{abstract}
This article explores the creation of the "Radar in Amazon Project" (RADAM), a technoscientific project developed through a joint Brazil/United States technical cooperation, originally designed for Amazon territorial mapping in 1970 and then extended to national territory in 1975. More specifically, the article discusses the role of humans and non-humans during the project's survey of the country's natural resources that took place during the Brazilian dictatorship (1964-1985), with particular focus on how nature challenged the program. By analyzing original documents such as reports, ordinances, scientific papers, and newspapers available at the National Archive of Brazil and the Brazilian Institute of Geography and Statistics, this article discusses the entanglements between humans and non-humans in the formation of the RADAM; in addition, we explore how the project contributed to the development policy set forth by the military government. The paper is divided into four sections. First, technical cooperation between Brazil and the U.S. after World War II. Second, the creation of RADAM. Third, the role of the non-human/human assemblages within the emergence of radar as a new technology. Last, the paper discusses how the state mobilized RADAM's achievements as a pillar of support for the dictatorship.
\end{abstract}

Resumo: O objetivo do artigo é explorar a criação do "Projeto Radar na Amazônia" (RADAM), um projeto técnico-científico desenvolvido por uma cooperação técnica conjunta Brasil/Estados Unidos, originalmente projetado para o mapeamento territorial amazônico em 1970 e depois estendido ao território nacional em 1975. Mais especificamente, discutimos o papel de humanos e não-humanos durante os trabalhos de levantamento dos recursos naturais em toda a ditadura brasileira (19641985), com foco em como a natureza desafiou este programa. Analisando documentos originais como relatórios, portarias, artigos científicos e jornais disponíveis no Arquivo Nacional do Brasil e na Fundação IBGE, discutimos as relações entre humanos e não-humanos na formação do RADAM; além disso, exploramos como o projeto contribuiu dentro da política de desenvolvimento autoritário estabelecida pelo governo militar. Para alcançar nossos objetivos, organizamos o artigo em quatro tópicos. Primeiro, discutimos a cooperação técnica entre o Brasil e os Estados Unidos após a Segunda Guerra Mundial. Após, definimos o processo de criação do RADAM. Sequencialmente, afirmamos o papel dos agenciamentos não-humanos/humanos no surgimento do radar como uma nova tecnologia a ser utilizada. Por último, apontamos como o Estado mobilizou as realizações do RADAM como um pilar de apoio a ditadura. 
In the early years of the military dictatorship, a group of United States and Brazilian technicians with financial support from the Inter-American Geodetic Survey (IAGS) developed the "Radar in the Amazon" (RADAM) project, which aimed to survey natural resources. Created at the federal level in 1970, the project was intended to obtain detailed information in the North and Northeast of Brazil, with particular focus on the Amazon, but also parts of the surrounding semiarid territory. After its first successful activities, the Brazilian federal government expanded RADAM to cover the entire national territory in 1975. In this perspective, this article explores the creation of the RADAM and its influence in Brazil after the civil-military coup of 1964. During the dictatorship (1964-1985), scientific activities such as mapping and surveying natural resources occupied a central position within national development plans (Silva, 2011, p.13; Mello, 2017, p. 67; Josephson, 2016, p. 161). Reflecting on the years following the 1964 coup, Brazilianists and Brazilian historians have pointed to the emergence of a technocratic administration that rearranged the apparatus of state through the creation of new agencies, institutions, laws and development programmes. Hence, analyzing the role of the RADAM project contributes significantly to understanding the place of technology, science, and the environment in the process of reconfiguring social, economic, and ecological relations in the context of the new political arrangement of the military dictatorship (Padua, 2017, p. 31; Klanovicz, 2019, p. 04).

By analyzing the original documents available at the Brazilian National Archive and the library of the Brazilian Institute of Geography and Statistics (IBGE), this article argues that the RADAM Project was a fundamental part of the Brazilian State's biopolitics. Following this perspective, the aforementioned project produced a new arrangement of power-knowledge that set forward certain conceptualizations of the imagined Brazilian nation. Through this new arrangement, the Brazilian State acted by organizing and hierarchizing human and non-human elements according to the preferred ideal of the nation according to the military governments and civil elites with the most influence over government actions. According to Foucault, biopolitics is a set of mechanisms through which politics, in a broader strategy of power, absorbs the biological aspects of life (Foucault, 1998, p.139; 2003, pp. 241-247; 2007, p. 16). Beyond this one-way approach, biopolitics should also emphasize the dynamics of power across the different non-human elements involved, as well as trying to understand the role of scientific knowledge within the spectrum of biopolitics (Cruz and Silva, 2020, pp. 53-56). Both theoretically and methodologically, therefore, the present discussion is situated at the intersection between Environmental History and History of Science, and seeks to reinstate the human element in a world populated by diverse beings and forces that exceed only human communities and their institutions (Worster, 1991, pp. 201-202). On the other hand, this paper intends to understand how technology and science mediate human relations with non-human elements, grounding certain ways of seeing and acting in the world, as well as creating categories and classifications regarding objects of knowledge (Anderson, 2002, p. 644). In a 
complementary perspective, the notion of assemblage simultaneously involves both material and semiotic regimes. It involves signs that give meaning to the material world and offer a way of organizing bodies that act and react, affecting each other mutually and in constant interaction (Deleuze and Guattari, 2000, p. 23; Goldstein and Zourabichvili, 2004, p. 24). The notion of assemblage can be extended to recognize the relationships between human and non-human elements in the configuration of the material world. As has already been demonstrated by Jane Bennet (2010, p. 23), thinking about the power of agency through the assemblage makes us able to encompass the sensitivity, flows, forces, and effects that emanate from beyond the human world. While extrapolating the purely human dimension of things, it becomes possible to show the acting power of non-human elements.

Therefore, by combining this conceptual framework with archival research, this paper aims to outline the connection that enabled the emergence of the RADAM project, and at the same time learn more about the multiple agents and forces that participated in its construction through opposing or collaborating with one another for given desired outcomes. First, however, it will explore the emergence of technical cooperation programs and their connection to the creation of RADAM in 1970.

\section{Before Radar in the Amazon: Brazil/U.S. cooperation programs after WWII}

After the civil-military 1964 coup, one of the government's first measures was to resume technical cooperation projects with the United States of America, foreseen in the Agreement for Special Technical Services, signed in the 1950s (Mello, 2018, p. 18). The book of legislative decrees of 1964 shows that the terms of the agreement were renewed and published in an Official Bulletin. This document confirmed the commitment between Brazil and the U.S. to carry out cartographic projects in Brazil as well as other aspects of technical cooperation (Brasil, 1976, p. 680). In July 1964, the aerial survey operation for the cartography of the national territory began. In compliance with the cooperation agreement and at the confluence of interests of Brazil and the U.S.; the execution of the project was in charge of the 10th Group of the Air Survey Squadron of the North American Air Force (Aerial Squadron Team 10 - USAF - AST10). The organization of the project was the direct responsibility of the General Staff of the Armed Forces (EMFA) on the Brazilian side, and IAGS on the U.S. side (Mello, 2018, p. 18). On the Brazilian side, representatives of various institutions constituted the group assigned to manage the processes of aerial survey. This included members of the IBGE, Directorate of the Army Geographic Service (DSG), Hydrography and Navigation Directorate (DHN), Aeronautical Air Routes Directorate (ROTAER), and National Observatory $(\mathrm{ON})$. However, the presidency of the Joint Executing Commission of the Brazil-United States Agreement on Cartographic Services (CMEABEUSC) always had a superior officer of the Armed Forces (General, Admiral or Brigadier) (Mello, 2018, pp. 18-19). 
The resumption of activities in the technical cooperation plan between the United States and Brazil marks what Antonio Pedro Tota called a "Marshall Plan for the poor" (Tota, 2017, p. 70), in reference to the European Recovery Plan (ERP). The ERP, a plan for the reconstruction of European countries affected by World War II, offered concrete conditions for the recovery of these nations. However, for countries considered underdeveloped like Latin American countries, the projects were established in other terms with the promise of a world in which technology would be the "salvationist chimera" (Tota, 2017, p. 70). In fact, the relationship between Brazil and the U.S. was re-elaborated under the military governments, gaining new components as the Cold War unfolded. Nevertheless, and as has already been demonstrated by Brazilian scholars these relations had a longer history since the American state and private agents had been working on Brazilian territory for some time (Silva, 2009, p. 81). Brazilian and American agents considered that solutions to Brazilian national problems could be achieved through a technological package, in imitation of American standards. However, these processes cannot be summarized merely in the transposition of American techniques and technologies for Brazilian land. Likewise, it is also impossible to authenticate that foreign forces imposed the entire modernizing program. As will be demonstrated, the desires and aspirations of the agents involved in the programs that preceded the founding of RADAM form a complex network within which asymmetries of power and divergent interests emerge.

The Brazilian government's objective was to fulfill the agreement and secure effective gains with North American assistance. While a squadron of the North American Air Force, the AST10, carried out the aerial survey activities, ordinances and information about their activities was circulating in the offices of the EMFA and CMEABEUSC and proposing potential outlines for future projects to achieve the proper development of national cartography. Therefore, in July 1965, the president of CMEABEUSC produced a detailed report for the chief of EMFA about the cartographic situation in Brazil and emphasized the importance of organizational procedures to put government plans into action. Among the many topics covered, the relevance of the mapping and the construction of adequate knowledge about the national territory was consistent (CMEABEUSC, 1965, p.02). Other complaints were about the "poverty" (CMEABEUSC, 1965, p.09) of national cartography. The lack of data was making the planning of development actions unfeasible and the guidelines for the centralization of the coordination of activities had become necessary in order to produce and systematize knowledge about the territory (CMEABEUSC, 1965, p.09). In this way, the use of the aerial photography coverage carried out by the AST-10 did mean that considerable advances were being made in terms of updating information on regions that had already been mapped on less precise and detailed scales, and, even more crucially, regions that were harder to access. The plan for the activities of AST-10, which was presented by CMEABEUSC, pointed out the reasons why the work executed by the U.S. air squadron was being carried out. 
The work developed by the AST-10 was considered advantageous by the Brazilian administration. Both economically and technically, the work of AST-10 agents was seen as a crucial part of obtaining the best possible quality data and in the fastest way. These facts would enable the effectuation of data surveys useful for rapidly formulating the full basic cartography of the country. However, these initial aerial photographic surveys in areas 1 to 8 south of the $14^{\text {th }}$ parallel, covered only the South-Central area of Brazil, since the aforementioned parallel is an imaginary line that divides Brazil in two, passing through the states of Bahia, Minas Gerais, Goiás, and Mato Grosso (Image 1) (EMFA, 1966, p. 37). Notwithstanding the promising initial work of U.S. agents, a series of challenges arose for the national organization of maps. In 1966, the CMEABEUSC secretary had written an official report on the use of the photographic coverage being carried out by the AST-10. In his assertions, he reinforced the urgency of elaborating an institutional apparatus that would provide more effective use of the North American efforts in Brazil. The goal was to carry out mapping that would allow the implementation of developmental projects in the short term (EMFA, 1966, p. 34).

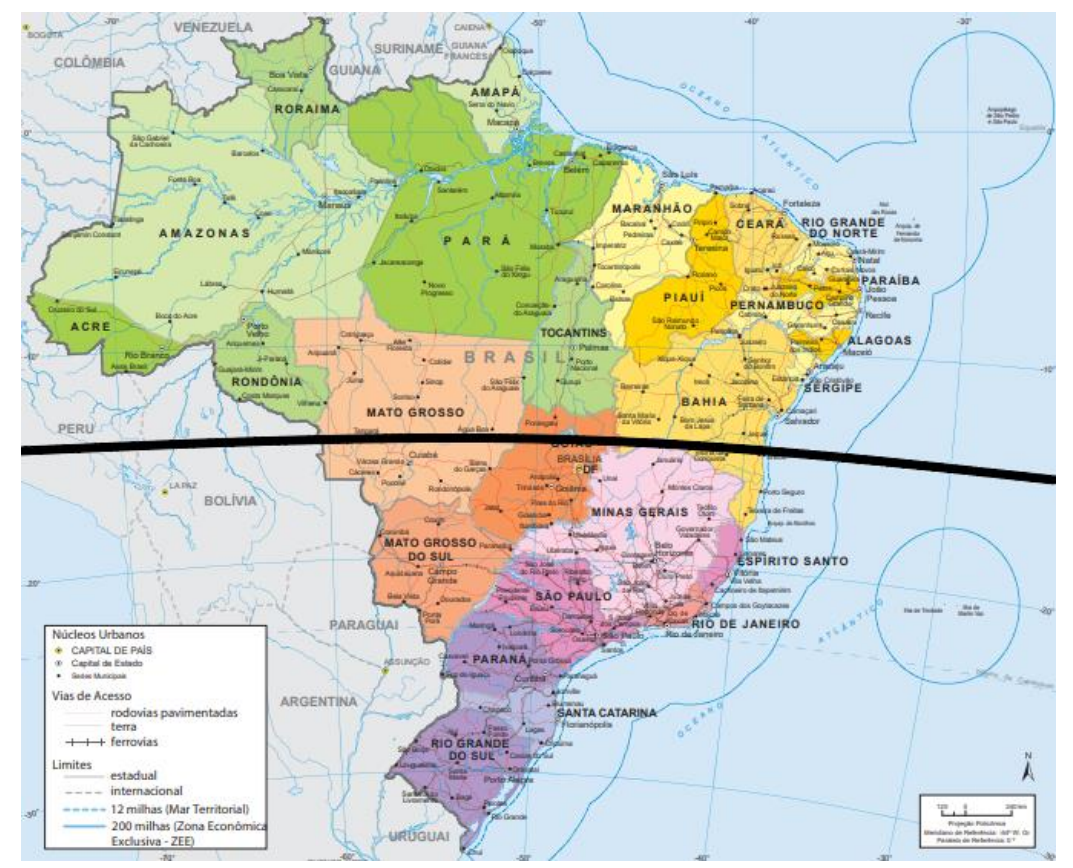

Image 1: Approximate marking of the 14' South parallel. Adapted from IBGE (2021).

The secretary's analysis continues to denote the importance of the Brazil-U.S. agreement. Both governments considered the cooperation program as crucial "for the preparation of topographic and aeronautical maps in Brazil" (EMFA, 1966, p. 37). These results allowed the Brazilian state to intensify its "cartographic activities and provide conditions for the improvement and modernization of our [Brazilian] official cartographic organism and its technical evolution" 
(EMFA, 1966, p. 37, own translation), while the Brazilian government itself would be better equipped to solve a multitude of existing problems (EMFA, 1966, p. 37). While Brazilian institutions and agents were concerned about the institutional, legal, and administrative prerequisites for standardized and systematic cartography, the technical and indirect financial assistance provided by the U.S., through the IAGS, can be seen through the "volume of technical material and motor vehicles given to our mapping groups" (EMFA, 1966, p. 35, own translation). What also represented U.S. assistance was the cooperation given to Brazil by the introduction of new methods and professional training, as well as generous financial assistance in many millions of dollars (EMFA, 1966, p. 35). Consequently, the IAGS assumed the prominent role of carrying out the aerial survey's activities. The work done by the North American institution was considered an "instrument of active and efficient cooperation" that acted to remedy the "deficiencies" of Brazil's cartographic organization and the "inequality of productivity and techniques" (EMFA, 1966, p. 36, own translation). Mostly through information, indirect financial assistance and borrowed technical equipment, IAGS support was seen by the CMEABEUSC secretary as a "true donation" (EMFA, 1966, p. 36, own translation). Other IAGS actions were considered even more fundamental, such as the help through human experience achieved by experts and through preparation and improvement of the technical teams. Therefore, all efforts undertaken would aim at "the progressive elimination of the economic imbalance and the unevenness of progress between the least and most developed nations" (EMFA, 1966, p. 36, own translation). From the Secretary of the CMEABEUSC perspective, the IAGS "brought us scientific knowledge, technological capabilities and executive experience" (EMFA, 1966, p. 36, own translation). Still, he referred to the fact that "the administrative, technical and scientific brains of the operation that was still hosted in the U.S." while Brazilian participation was limited to the "authorization and observation of what was being executed in the country [Brazil]" (EMFA, 1966, p. 36, own translation).

Finally, the notes of CMEABEUSC's secretary highlight important aspects of the construction of knowledge about the national territory. First, North American technical and financial investments were seen in a positive light, not only for the execution of services within Brazil, but also for the opportunity they presented to acquire knowledge from foreign agents. Second, although understood almost in terms of a donation, the report underlines that only a portion of the techniques and technologies would actually be available to Brazilians. Third, the provision of services from AST-10 and IAGS has accelerated certain administrative and legal reforms in order to continue the modernization project. Finally, it highlights the significant role of Brazil-U.S. cooperation in order to transform the surveys into cartographies and be able to plan and carry out government projects.

The optimism on the part of Brazilian management at the beginning of the aerial photographic survey activities is notable. In addition to the urgency with which new administrative procedures were adopted to keep up with the work of U.S. agents, the positive results of the first 
surveys carried out by the AST-10 encouraged the expansion of the project to cover the entire national territory. The requests for aerial photographic coverage from several Brazilian institutions ended up causing the EMFA to allow foreign agents to fully cover the Brazilian territory (EMFA, 1966, p. 37). The success of the experiments carried out in areas 1 to 8 opened up the prospect of carrying out a total survey of the territory using aero photogrammetry. Therefore, the mapping works embraced the rest of the 14 priority areas. Expecting to receive another aircraft (the plane RC130) in June 1966, the CMEABEUSC simply waited for the Brazilian government to authorize the use of "auxiliary electronic equipment SHORAN for orientation, photogrammetric flights" and "Automatic Transmitter System of Photography (APT) with the use of a meteorological satellite increasing the chances of success of the project" (EMFA, 1966, pp. 39-40, own translation). The Brazilian government expected that this would make the project more agile, economical, and efficient, hoping to soon expand the photographic coverage to the Northeast, the North of Goiás and the Amazon (EMFA, 1966, pp. 39-40). The prospect for expanding the photographic coverage of the AST-10 shows the optimistic expectations of the Brazilian government, as it estimated that full surveys could be complete by 1970 (EMFA, 1966, p. 40). From this perspective, the committee expected that total coverage of Brazil through aerial photographs would be complete by October 31, 1970. At this point, they expected to be able to begin building cartographic maps by 1967 by giving subsidies to local, regional, and national planning agencies (EMFA, 1966, pp. 54-55).

The documents analyzed clearly understood the importation of techniques and technologies as the only way to overcome economic and social "backwardness" in Brazil. From this perspective, it was crucial that Brazilian agencies and institutions should seek the best possible ways to make the most of the benefits provided by the American government through state or private agents. However, there were divergences in the national interests of Brazil and the U.S.. While Brazilian agents sought a way to bring Brazil into the same category as developed countries, the American government essentially sought to establish an important area of influence in Latin America, trying to ensure the removal of the communist spectrum that hovered over the region especially after the victory of the Cuban revolution. Thus, the asymmetries of power among the agents that co-form the mapping of the national territory are exposed. There are two different places for Brazilians and Americans. The viewpoint of CMEABEUSC indicates an understanding of different roles in which Brazil acts as the place to be investigated, while North American institutions are understood as the "brain" of the carried-out activities. It should also be added that both Brazilian and North American agents understood the territory as a mere object to be known, without taking into account the participation of the natural elements themselves in the construction of the knowledge that was intended to be registered. As will be shown, the environment forced a change in perception and imposed the need for a major readjustment in the program. The following section will discuss the official creation of the RADAM Project during the dictatorship. 
Cruz, Leandro Gomes Moreida; Silva, Claiton Marcio da. The clouds against progress: technoscience, environment and the U.S./Brazil "Radar in Amazon Project" (RADAM) (1970-1975).

\section{The RADAM}

To begin with, it is necessary to paint a picture of the internal structure of science and technicians in the military governments. Brazilian historian Marco Napolitano highlights the dictatorial governments' tendency to distribute strategic positions between "military" and "technocrats" (Napolitano, 2014, p.73). Following this argument, technocrats and the military worked together to build a rhetoric on the need for technical modernization of mapping process in Brazil. Napolitano also argues that this "technobureaucracy" - the intellectuals recruited in the academic sphere - were part of a mechanism that established a neutral image of the development and modernization plans of the military dictatorship (Napolitano, 2014, p.163). In addition, the Brazilian sociologist Octavio Ianni clarifies how the work of intellectuals and scientists contributed to the authoritarian governments, encompassing all aspects of social life. Ianni also argues that the military government expanded economic planning beyond its more stricto sensu understanding, seeking to encompass strategic fields such as science, technology, and education, among others. Thus, the articulation of a science and technology policy, adjusted to economic development strategies, was crucial to the feasibility of Brazil's economic development, replacing the "political" with science and technology (Ianni, 2019, pp. 49-50, 65). In other words, the military government used the rhetoric of objectivity, pragmatism, efficiency, performance, modernization, development, and progress to connect science/technology, politics, and economics, while aiming to present itself as neutral and impartial. The governments of the Brazilian dictatorship used this mechanism to ensure the stabilization of power over society and build their legitimacy both nationally and internationally.

This technocratic government transformed the position of certain regions of the country like the Midwest and the Amazon in the geopolitical spectrum. During the dictatorship, military governments radicalized this concern and turned it into a "geopolitical imperative" (Pádua, 2000, p. 804). From this imperative, an effort was made to reform or reconstruct the State's legal, technical, and institutional apparatus to promote "development" and "modernization" (Silva, 2014, pp. 12-13). On one hand, this process implied a need for transformations in social, economic, and ecological relations aiming for the national economy's more effective insertion into the world market. On the other hand, this geopolitical imperative also incorporates the doctrine of National Security. ${ }^{1}$ So, the military aligned the propaganda of national unity and integration with the need for dominance, control, and regulation of the territory's borders (Araujo, 2019, p. 61). Thus, the military's authoritarian escalation established a premise that it was crucial to occupy the Amazon as soon as

\footnotetext{
${ }^{1}$ The principles of The National Security Doctrine were formulated and developed within the Escola Superior de Guerra (ESG). The ESG had been created in 1949, inspired by the National War College, an American military training school responsible for the development of the doctrine. The main conception of the doctrine was that without a strong internal security scheme it would be impossible for a country to develop economically (SANTOS, 2016, p. 86).
} 
possible in order to guarantee political control of that territory. The political rhetoric of the demographic void was mobilized and the obligation to set national entities along the country's borders was established. For this to take place, it was necessary to create infrastructural conditions and incentives for any type of economic activity and labor that might be classified as a "Brazilian presence" in the Amazon (Pádua, 2000, pp. 804-805).

In the midst of this process, the state created or reformulated several institutions and legislations arguing that it was necessary to guarantee national security and the economic development of the country. Legislatively, the Brazilian State created the Land Statute (Law $\mathrm{N}^{\circ}$. 4.504/1964), the Forest Code (Law $N^{\circ}$. 4,771/1965), the Law on Protection of Fauna (Law $\mathrm{N}^{\circ}$. 5,197/1967), and the Fisheries Code (Decree-Law N.221/1967). Because of these laws, the Brazilian Institute for Agrarian Reform (IBRA) and the National Institute for Agrarian Development (INDA) were created at the institutional level, both related to the promulgation of the Land Statute, which would later merge into the creation of the National Institute of Land, Colonization, and Agrarian Reform (INCRA) in 1970. In addition, a legal apparatus aimed to standardize the forms of access and occupation of the land and the possibilities of the socio-ecological relationship between humans and non-humans. Meanwhile, the legal-institutional framework intended to organize and regulate a program for the production of knowledge about the nation.

Within this context, Decree $N^{\circ} .57814$ of $15^{\text {th }}$ February, 1966 set the composition of the Brazilian delegation in executing the joint committee of the Brazil-U.S. agreement regarding mapping services; Decree $N^{\circ}$. 58733 of June 27th 1966 , promulgated the agreement for the preparation of topographic maps and aeronautical charts in Brazil with the United States; DecreeLaw $N^{\circ} .161$ of February 13 ${ }^{\text {th }}, 1967$, authorized the Brazilian Institute of Geography and Statistics (IBGE), the National Plan for Statistics, and the National Geography Plan and Cartography Land; finally, Decree-Law $N^{\circ} 243$, of February $28^{\text {th }}$, 1967, established the Guidelines and Bases of Brazilian Cartography, creating a unique system titled the National Cartographic System (SCN). Sequentially, the Cartography Commission (COCAR), an organ of the IBGE Foundation, was to keep the task of coordinating the implementation of the National Cartographic Policy, being made up of representatives of the Navy, War, Aeronautics, Agriculture, Mines and Energy, and the National Association of Aerial Photography Companies (Ugeda Sanches, 2014, pp. 221-222). These new state institutions were expected to organize data about the national territory and foster national development. The particular concern with knowledge about the territories brings up the relevance of the mapping process for the state. Thus, maps "are engines that convert social energy to social work", linking "things in space" (Wood, 2010, pp.1-2). Wood's observation clarifies why mapping was a huge issue for the Brazilian dictatorship: if the government aimed to integrate the nation, they needed something to link spaces that were not considered integrated. This was what motivated such investment into the great struggle of planning mapping programs. 
The construction of legal and institutional structures for this geopolitical project is detailed through the military government's interactions with the National Integration Program, created by Decree-Law N $N^{\circ} .1106$, of July $16^{\text {th }}, 1970$. Decree $N^{\circ} .67,113$, of August $26^{\text {th }}, 1970$, dealt with regulating the National Integration Program, established several objectives surrounding the economic development of the country. Among these objectives, an extensive list of tasks including "the immediate construction of the Transamazônica and Cuiabá-Santarém highways" (Projeto RADAM, 1971, p. 03, own translation), under the responsibility of the Ministry of Transport. It would also establish colonization projects and agrarian reform through the Ministry of Agriculture and "the survey of topography, forest cover, geomorphology for mineral research and energy sources, the nature of the soil, the respective drainage and the unit" (Projeto RADAM, 1971, p. 03, own translation), which would be executed by Ministry of Mines and Energy. This last assignment of the PIN, linked to the Ministry of Mines and Energy, worked as an engine providing the creation of the RADAM Project, as shown in one of the first reports of the program (Projeto RADAM, 1971, p. 03).

Officially, the commission responsible for executing the RADAM project was created by Ordinance $N^{\circ}$. 2048, 1970, from the Ministry of Mines and Energy. As pointed out in the first activity report, the project had as its objectives: "administration, control and monitoring of the survey by radar images (Side-Looking Airborne Radar - SLAR) and other remote sensors" (Projeto RADAM, 1971, p. 04, own translation). In addition, it should cover "part of the North, Northeast and Midwest regions of the country [...] with the goal of obtaining a mosaic map at scale 1:250,000 and thematic maps of forest cover, geology, nature, soil and surface drainage" (Projeto RADAM, 1971, p. 04, own translation). However, the natural world did not engage in the project with the same enthusiasm.

\section{The clouds against progress: human and non-human assemblage}

The promising expectations of the first aerial photography coverage of the AST-10 led to an aerial survey program that intended to produce an integral map of all territory and natural resources of the Brazilian State. However, the success and agility of the aerial photography coverage that took place South of the $14^{\circ}$ parallel could not be automatically reproduced in other areas of the country. A 1969 report from CMEABEUSC informs that the aerial photography of the national territory by the AST-10 / USAF had been taken with "panchromatic films of topographic basis, usual in this type of work". Notwithstanding, when the AST-10 tried to use the same technology in the North of Brazil, certain adversities for completing the work were revealed. Facing the climate conditions in the Amazon and Northeast Coast, the agents in charge of the aerial photogrammetry described "adverse weather conditions" responsible for the continued existence of clouds "caused by the high degree of humidity" (CMEABEUSC, 1969, p.01, own translation) that makes the use of this film unsuitable. Thus, the capacity for non-human elements to oppose the power of technology was revealed. Due 
to the humidity of the air and the distinct atmospheric conditions of the vast Brazilian territory, new arrangements for the aerial photographic project were required.

As one might imagine, the solution for this issue was technological. To overcome the difficulty, Brazilian representatives proposed the use of the infrared film to CMEABEUSC (CMEABEUSC, 1969, p.01). Thus, in view of the weather conditions, infrared films were proposed as a way of overcoming the atmospheric density on the coastlines and in the Amazon. Nevertheless, new tensions and negotiations between Brazilians and Americans in defense of their own interests began to appear.

Two years earlier, in 1967, the North-American commission had suggested a way to improve the mapping methods. The use of radars was the solution offered by the Americans, but the Brazilian government denied it (CMEABEUSC, 1969, p.02). From the commission's refusal of the North American proposal, we can indicate certain points of tension. The military dictatorship needed a pillar of support for the authoritarian regime. The regime's stability has been achieved mainly through the establishment of binomial national security and development. All this considered, it is possible to assume that the Brazilian federal government did not wish to serve as a testing laboratory for new technologies. It was necessary to be sure of a functional program with immediate applicability for economic development. Still, it would be reasonable to question whether it was in the interest of Brazilian agents that the information obtained by radar photography would be available for foreign use, considering that through radar they would obtain mapping with a greater amount of information on the resources available in the territory. In any case, the national security concerns delayed any rush to carry out the coverage and mapping of the nation.

Two years later, in 1969, new discussion about the better technology to finish de mapping process started. This time, "the American delegation proposed to the Commission [CBEAMEUSC] in its letter $n^{\circ} 60 / 69$ of September 5 a performance of a comparative test, at different altitudes and scales of panchromatic and infrared photographs" (CMEABEUSC, 1969, p. 02, own translation). It would ensure that such photographs would be taken "simultaneously by AST-10 and FAB [Brazilian Air Force] teams, both employing two overhead cameras of the same characteristics" (CMEABEUSC, 1969, p. 02, own translation). In view of the impossibility of carrying out the cartographic services considered crucial for governmental actions, the interpretation would have to be more careful in order to solve the problem of the clouds. The proposal of using infrared films was the first, but it came at a time of other difficulties present at this early stage of the project. Furthermore, in the same report, the president of the commission noted that the "film sensitive to infrared rays, especially to near-infrared, can penetrate that veil, fixing more precisely distant points and defining absolutely the contrast earth-water, not transposing, however, clouds and rain" (CMEABEUSC, 1969, p. 02, 
own translation). Exposed to the limitations of infrared films, the last viable option would remain to be the use of radar photographs suggested two years earlier by the American delegation.

Facing these new conditions, the Brazilian delegation had to accept the last viable option of running the aero photogrammetric survey. The solution was discovered by the commission due to the possibility of using "the photograph radar combined with that film [infrared]" (CMEABEUSC, 1969, p.02, own translation). To justify accepting the use of radar photographs at the time, the president of CMEABEUSC argued that the project was no longer experimental. Having explained the reasons for adhering to radar photographs in aerial survey projects, the leader of CMEABEUSC questioned the Chief of EMFA about the security-related "restrictions" that may exist regarding the use of "infra-red film, radar photography, aerial photography and mapping areas of our territory under the conditions indicated above" (CMEABEUSC, 1969, p.02, own translation). Nevertheless, he reinforced his demand for new technologies in order to accomplish the national cartographic project. Reaffirming that remote sensors [infrared and radar] would suit for different purposes like "the identification of plants, hydrology and contrast of the land-water contact, the coarse chemistry of the rocks and the basic topographic mapping, and also in Geology, Agriculture and Oceanography in a lower priority" (CMEABEUSC, 1969, p.03, own translation), the CMEABEUSC secretary was receptive to the use of the radars and infrared.

In response to the request from CMEABEUSC, a new EMFA directive provided guidance on the execution of infrared and radar photographs. The demand for the combined use of the radar and infrared mechanisms would aim to "overcome, in excellent conditions of image, resolution and contrast, the veil of humidity that covers the Amazonian forest and coastal area and the almost permanent presence of clouds over the respective regions" (Brasil, 1969, p. 01, own translation). In reports on the aerial survey, work groups specified the problems that might be faced in certain areas in greater depth. Upon the verification of the critical situation regarding the continuity of photographic coverage of the regions, the report reached its conclusions. The efforts undertaken by AST-10 since the beginning of its activities in Brazil and even counting on the "assistance provided by the APT system" had so far founded "great difficulty and delay in its aerial photogrammetric coverage by panchromatic film and likewise in the remaining Amazon and coastal regions" (Brasil, 1969, p. 01, own translation). Therefore, the report recommended "examining the possibility of utilizing infrared film and photo radar in aerial photogrammetric to cover the areas of the Amazon and the coast" (Brasil, 1969, p. 02, own translation). The approval for the use of infrared and radar coverage (Brasil, 1969, p. 05) was accompanied by reports on the experiences of other countries and evaluations of companies' and institutions' ability to run the service, whether private or managed by the American or Brazilian governments (Brasil, 1969, p. 03). 
When permission was granted for surveys to use radar technology, the programs could move forward. The last annotation that appears in the report draws particular attention because it indicates the existence of a new project. A program called Project SERE - Remote Sensors - had been developed by the "CNAE [National Commission for Spatial Activities] and NASA" (Brasil, 1969, p. 06, own translation). According to the report, the project involved "the sensing (with infrared and radar, inclusive)" of certain test areas. Among them the "Santa Elisa Farm in Campinas (of agricultural interest)", the "Iron Quadrangle (geological)", the "Paraíba River region (hydrological)”, "Cabo Frio and Guanabara Bay (oceanographic and pollution)”, all places that had only ever been conventionally surveyed (Brasil, 1969, p. 06, own translation). These radar and infrared tests were initially intended to "deduce interpretation keys for Brazilian conditions" and their results were already "being processed in the United States" (Brasil, 1969, p. 06, own translation).

The North American cooperation was taking place on distinct fronts. Beyond the work of CMEABEUSC and the AST-10, CNAE and NASA had been working even in areas related to cartographic services. In addition, these events show that despite the government's refusal in 1967, the interest in new methods of obtaining information about national territory was now on the agenda. These events show the negotiation of both governments in an attempt to achieve their individual objectives, but also show a certain impossibility in simply transposing technical and technological systems from the American context to Brazil. Challenges such as the Amazonian clouds could not be disregarded in order for both nations' wishes for progress to be fulfilled. Still, the clouds and rains of Brazilian coastlines and forests participated in the production of knowledge of the national territory, since it is likely that without the interference of the "veil" that covered the forest, the survey would have been carried out through conventional aerial photographic coverage. It is important to remember that it was precisely within the SERE project, that a project with the name "Radar in the Amazon" was proposed, suggesting that perhaps the Amazonian atmosphere was decisive in the way the project ended up being developed. Not without reason, in the justification for submitting the plan for the sub-project Radar in the Amazon, it is stated that radar could be applied to any weather conditions. (Brasil, 1969, p. 11).

\section{Radar in the Amazon: the conquest of the forest}

The climate issue pushed the management of aerial photography activities to adapt itself to the humid atmospheres of Brazilian forests and coastlines. Due to this, the RADAM subproject was elevated to a prominent position within the dictatorship's development program. After the tests carried out in 1969 obtained satisfactory results, an experimental area in the Amazon region was selected to prove the efficiency of the new infrared and radar technologies. This new project was no longer directly linked to EMFA, but linked to the Ministry of Mines and Energy, through the 
National Department of Mineral Production. Initially, a survey of an area of $44,000 \mathrm{~km}^{2}$ was proposed in the Amazon region of the Tapajós River (Projeto RADAMBRASIL, 1979, p. 03). This first survey appears in subsequent reports as the moment it was understood that "advanced methods" such as SLAR (Side-Looking Airborne Radar) would be necessary. It was suggested that this would be the only possible way to survey the natural resources of the Amazon at a low cost and within feasible terms given the adverse weather conditions in the region. Hence, in 1970, when the PIN and subsequent creation of the RADAM executive commission took place, the project became official in the format that made it known as one of the greatest efforts to map and survey resources in Brazilian national history (Projeto RADAMBRASIL, 1979, p. 06).

In the reports of the late 1970s, after the work of the RADAM project (nationalized after 1975, renamed RADAMBRASIL), the program's origin is explained as a "coincidence" between the objectives from both PIN and de Ministry of Mines and Energy (Projeto RADAMBRASIL, 1979, p. 06). However, as has been shown, throughout the report, there is no coincidence in the creation of the mapping project and its incorporation into the PIN. For more than half a decade, government institutions aided through cooperation with the U.S. were looking for a way to carry out a program of national mapping. The mapping projects would have the purpose of subsidizing the federal government's developmental actions from the beginning. Considering this, we should not assume that it was by chance that certain territories were chosen for the project. For instance, the construction of the BR-230 highway, the Transamazônica, corresponds exactly to RADAM's first areas of interest (Neto, 2013, pp. 283-285).

Moreover, the order of events suggests that the RADAM was a great tool for governance. The mapping activities carried out by RADAM, although aimed at surveying natural resources, were not just carried out to support government planning. A concomitant activity sought to provide legitimacy to the geopolitical projects of the military dictatorship to occupy the Amazon. Furthermore, the unfolding of the project continued to count on important national and North American contributions. Earth Satellite Co., a U.S. company, was contracted to provide technical assistance and to be in charge of preparing specifications and acquiring ground data, inspecting and accepting final images and mosaics (Lima, 2018, p. 20). Additionally, the Brazilian company Lasa Engenharia e Prospecções SA, associated with Aero Service and Corporation of the US, was contracted to execute the flights, establish the ground controls and build the semi-controlled mosaics (Lima, 2018, p. 20). So, the powerful technoscientific assemblage that had been built over the years took the form of state policy. Within this assemblage, the SLAR was portrayed as an agent of progress, enabling Brazilian humans to finally overcome the uncompromising Amazon.

The activities of the RADAM were largely disseminated by the federal administration through media and scientific events. The project was described in the newsletters of the Brazilian 
Army: "such radar provides images that closely match the accuracy of conventional photographs" and "with the advantage of the enormous capacity of penetrating clouds, fogs and the Earth's surface, managing to reveal geological data that is beyond ordinary photos" (Sensor, 1971, p.61, own translation). At the beginning of the 1970s, the visibility of the project amongst the Brazilian public was propelled by a report in the Jornal do Brasil (a media aligned with the official rhetoric of State), which described the RADAM as "winning the amazon" (MATHESON, 1971, pp. 29-32, own translation). The image built by the government was one of technology and science combined to overcome nature and the success of the project had two great benefits, at least for the military in power. Firstly, the benefit of better understanding the country's vast territories, which was necessary for better planning colonization and economic explorations, and second, it produced propaganda for the dictatorship as a modern administration, while minimizing news about the violence used against the opposition.

In addition to media coverage of the program's achievements, a similar rhetoric was produced within the scientific sphere. The project had been presented in specialized congresses, mainly by people involved in the activities of RADAM. Frequently, they pointed out the radar's capacity "to transpose the cloud formations and reach the ground, therefore, allowing an image entirely out of reach of the common aero photographic process" (ROCHA, 1971, p. 03, own translation). It was also clearly important to stress that the use of new technologies made it possible to identify "typical mineral deposits, including oil prospecting, knowledge of surface waters, assessment of the potential of the soil and its natural riches" (CORREAA, 1970, p. 04, own translation). The concern with minerals and other natural riches shows the link between science and technology and economic development. An important part of the RADAM's work was to subsidize the dictatorship in its economic development plans.

The perception of success allowed the RADAM project to expand successively until it reached an area of 4,600,000 $\mathrm{km}^{2}$ by 1972. Later, in 1975, the project acquired a national dimension, mapping the entire territory using the SLAR, infrared, and a series of other instruments. These technologies and related expertise were obtained from shared and accumulated experience, as well as the several national and foreign agents who worked on adapting the techniques, technologies, and scientific knowledge necessary to carry out the actions. On the other hand, the relative success of RADAM had not only subsidized the official rhetoric of modernization and the victory of technology and science over impenetrable forests, but also provided crucial legitimacy for changing landscapes and human occupation arrangements in the territory. The production of new cartographic knowledge added to a long list of experiences for the modernization of agriculture in the interior of the country, which also counted on North American cooperation (Biasillo and Silva, 2021, pp. 390-391). The advance in cartographic knowledge combined with experiments related to the modernization of agriculture enabled the Brazilian military government to scientifically build 
hierarchies of regions through the classification of soils, vegetation cover, the machinery appropriated to each region, and the type of human activity that was practiced. Thus, according to the findings of resources, it was intended to organize the human occupation of the territories in the same modernizing logic that during this period marginalized various peasant and indigenous communities who had occupied the territory often understood by the military regime as empty. Besides, the project frequently resulted in great devastation and disturbance of ecological balances. Considering these points, we argue that the RADAM project as acted as one of the key proponents of Brazil's military dictatorship.

\section{Conclusion}

The purpose of this paper was to trace the path taken by the Brazilian government during the military dictatorship in the construction of a huge survey of national territory and its natural resources. Thus, we attempted to elucidate a long journey marked by negotiations between Brazil and the USA to put in place a cooperation program that would make viable the surveys desired by both the Brazilian and American governments. We also highlighted the role that the mapping process played in connecting spaces like the Amazon region - often considered economically and socially disintegrated - to the rest of the national territory. Within this process, the nature of the assemblage of these projects was evidenced. Multiple agents of different nationalities and positions in the state hierarchy or within private institutions were identified, including non-human agents as well, such as clouds and climate. In particular, the presence of the Brazilian and U.S. militaries was very significant to the both CMEABEUSC and RADAM. After the coup, when the technocratic character of the federal administration was intensified, the technification of political relations and decision-making established a new form of governance. According to this understanding, we attempted to clarify the impacts of certain technologies and scientific studies during the Brazilian authoritarian regime, stating that technoscience was widely used as a pillar for the maintenance of dictatorship. However, it should be noted that these are just the first steps in a broader research project. There is a wider path to follow, including historically examining the relationship between technology, science, the environment, and politics that became intertwined in the constitution of projects like the RADAM.

\section{Bibliography}

Anderson, Warwick. (2002) Introduction: Postcolonial Technoscience. Social Studies of Science, v. 32, n. 5/6, p. 643-658. https://doi.org/10.1177/030631270203200502

Araújo, Gilvan Charles Cerqueira de. (2019). A Segurança Nacional No Regime Militarista. Observatorium: Revista Eletrônica de Geografia, v. 10, n. 1, p. 60-78, 2019. URL: http://www.seer.ufu.br/index.php/Observatorium/article/view/51115. 
Cruz, Leandro Gomes Moreida; Silva, Claiton Marcio da. The clouds against progress: technoscience, environment and the U.S./Brazil "Radar in Amazon Project" (RADAM) (1970-1975).

Bennett, Jane. (2010). Vibrant matter: A political ecology of things. Duke University Press. BIASILLO, Roberta; SILVA, Claiton Marcio da. (2021). The very grounds underlying twentieth-century authoritarian regimes: building soil fertility in Italian Libya and the Brazilian Cerrado. Comparative studies in society and history, v. 63, n. 2, p. 366-399. DOI: https://doi.org/10.1017/S0010417521000086

Cruz, Leandro Gomes Moreira; SILVA, Claiton Marcio da. (2020). Biopolitics and the Anthropocene era: Ideas of nature in Henry David Thoreau's Walden. JAm It!(Journal of American Studies in Italy), n. 3, p. 50-68. DOI: https://doi.org/10.13135/2612-5641/4231

Deleuze, Gilles; Guattari, Félix. (2000). Mil platôs: capitalismo e esquizofrenia, vol. 2. Editora 34.

Foucault, Michel. (1998). The History of Sexuality: 1: The Will to Knowledge. New York: Penguin. . (2003). Society Must Be Defended: Lectures at the Collège de France, New York: Picador. Macmillan. . (2007). Security, Territory, Population: Lectures at the Collège de France, 1977-78. London: Palgrave

Goldstein, Víctor; Zourabichvili, François. (2004). O vocabulário de Deleuze. [versão eletrônica]. Tradução André Telles Rio de Janeiro.

Ianni, Octavio. (2019). A ditadura do grande capital. Expressão Popular.

IBGE. Mapa Brasil Político. 2021. https://atlasescolar.ibge.gov.br/images/atlas/mapas_brasil/brasil_politico.pdf

Klanovicz, J. (2019). Amazônia em chamas e uma nova cidadania ecológica global. Estudios Rurales, 9(18), 10.

Lima, Mario Ivan Cardoso de. (2018). Descobrindo o caminho das rochas amazônicas. In: IBGE. Desbravar, conhecer, mapear: Memórias do Projeto Radam / RadamBrasil / IBGE, Gerência de Biblioteca e Acervos Especiais. - Rio de Janeiro: IBGE.

Mello, Mauro Pereira de Mello, et. al. (2018). Uma abordagem diacrônica sobre a influência da relação BrasilEstados Unidos no mapeamento do território brasileiro nas escalas topográficas 1:50.000 e 1:100.000. Terra Brasilis (Nova Série) [online]. DOI: https://doi.org/10.4000/terrabrasilis.3117.

Mello, Vanessa Pereira da Silva e. (2017). A EMBRAPA na Amazônia oriental: ditadura militar, desenvolvimento e ambientalismo (1972-1993). - Rio de Janeiro: Tese de Doutorado - História das Ciências e da Saúde) Fundação Oswaldo Cruz. Casa de Oswaldo Cruz.

Napolitano, Marcos. (2014). 1964: história do regime militar brasileiro. Editora Contexto,

Neto, T. O. (2013). Rodovia transamazônica: Falência de um grande projeto geopolítico. REVISTA GEONORTE, 4(12), 282 - 298. URL: https://periodicos.ufam.edu.br/index.php/revista-geonorte/article/view/1166

Pádua, J. A. (2000). Biosfera, história e conjuntura na análise da questão amazônica. História, Ciências, Saúde Manguinhos, vol. VI (suplemento), 793-811, setembro. URL: https://www.scielo.br/scielo.php?pid=S010459702000000500003\&script=sci_arttext.

Pádua, José Augusto. (2017) Brazil in the History of the Anthropocene. In: LÉNA, Philippe; ISSBERNER, LizRejane (ed.). Brazil in the Anthropocene. Routledge.

Josephson, P. R. (Translated by Klanovicz, J.) (2016). Big Science e Tecnologia no século XX. Fronteiras: Revista Catarinense de História, (27), 149-149.

Santos, D. G. E. D. (2016). Ciência, política e segurança nacional: o" Massacre de Manguinhos"(1964-1970) (Doctoral dissertation).

B 
Cruz, Leandro Gomes Moreida; Silva, Claiton Marcio da. The clouds against progress: technoscience, environment and the U.S./Brazil "Radar in Amazon Project" (RADAM) (1970-1975).

Silva, Felipe Maia Guimarães. (2014). Questão agrária e modernização no Brasil. Tese (doutorado) - Universidade do Estado do Rio de Janeiro, Instituto de Estudos Sociais e Políticos.

Silva, Claiton Marcio da. (2009). Agricultura e cooperação internacional: a atuação da American International Association for economic and social development (AIA) e os programas de modernização no Brasil (19461961) . (Tese de Doutorado) Casa de Oswaldo Cruz. Rio de Janeiro.

Silva, C. M. D. (2011). Ciência e nação: Nelson Rockefeller, o lbec Research Institute (IRI) e os caminhos da ocupação do Cerrado brasileiro (1946-1980). Simpósio Nacional de História-ANPUH, 26.

Tota, A. P. (2017). Um Plano Marshall para os pobres ou os caminhos da modernização brasileira. Revista USP, (115), 69-76. https://doi.org/10.11606/issn.2316-9036.v0i115p. 69-76

Ugeda Sanches, Luiz Antonio Mano. (2014). Geodireito e a Geografia de Estado no Brasil. Tese de Doutorado Universidade de Brasília. Programa de Pós-Graduação em Geografia. 2014, p. 221-222.

Wood, Dennis. (2010). Rethinking the power of maps. Guilford Press.

Worster, Donald. (1991). Para fazer História Ambiental. Tradução de José Augusto Drummond. Estudos Históricos, Rio de Janeiro, v. 4, n. 8, p. 198-215, 1991.

\section{Historical Sources}

Brasil. Senado Federal. Decretos legislativos - 1964. volume VI. Brasília-DF, 1976.

Brasil (1969). Estado-Maior da Foras Armadas. PARECER S/N. Brasília, DF. 06 Nov. 69.

BRASIL (1969?). Ministério das Minas e Energia. Projeto Sensores Remotos. Sub Projeto Radam-Radar na Amazônia. s.l. .

CMEABEUSC (1965). Of. $n^{\circ}$ 145/CMEABEUSC. Brasília, DF. CMEABEUSC, 05.jul 1965.

EMFA. CMEABEUSC (1966). Aproveitamento dos voos fotogramétricos realizada pelo AST-10/USAF. Brasília, DF.

CMEABEUSC. (1969) Of. n² 292/CMEABEUSC. Brasília, DF. CMEABEUSC, 03 out. 1969.

SENSOR Remoto vai mapear 1/6 do país. Boletim de Informações - EME -. s/l. mai/jun. 1971.

Matheson, Peter. (1971). Jovem com radar fixam nos mapas o futuro da Amazônia. Jornal do Brasil. [Rio de Janeiro]. 5 jul. 1971. p 29-32.

Rocha, Genaro Araujo da. (1971). A cartografia brasileira e a geodésia por satélites. V Congresso Brasileiro de Cartografia. Sociedade Brasileira de Cartografia. Brasília, DF.

Corrêa, H. Vaz. (1970). Levantamento radargramètrico da Amazônia no programa de integração nacional. $1^{\circ}$ Simpósio de sensores remotos da sociedade brasileira de cartografia. s.1

Projeto RADAM. (1971). Projeto Radam: relatório n. 1: resumo das atividades realizadas até 19/03/1971. Rio de Janeiro: Departamento Nacional da Produção Mineral, 1971. 17 p. In: IBGE. Desbravar, conhecer, mapear: Memórias do Projeto Radam / RadamBrasil / IBGE, Gerência de Biblioteca e Acervos Especiais. - Rio de Janeiro: IBGE.

Projeto RADAMBRASIL. (1979). Comissão Executora do Projeto Radambrasil: informações básicas 1. Rio de Janeiro: Departamento Nacional da Produção Mineral, 1979. 48 p. In: IBGE. Desbravar, conhecer, mapear: Memórias do Projeto Radam / RadamBrasil / IBGE, Gerência de Biblioteca e Acervos Especiais. - Rio de Janeiro: IBGE. 